Bull. Mater. Sci., Vol. 22, No. 4, June 1999, pp. 785-790. (C) Indian Academy of Sciences.

\title{
A matrix isolation FTIR investigation of laser-ablated uranium oxide in argon and nitrogen matrices
}

\author{
K SANKARAN, $K$ SUNDARARAJAN and $K$ S VISWANATHAN* \\ Materials Chemistry Division, Indira Gandhi Centre for Atomic Research, Kalpakkam 603 102, India \\ MS received 14 September 1998; revised 20 March 1999
}

\begin{abstract}
Uranium oxide was laser-ablated using the second harmonic of a Nd : YAG laser, and the products studied after trapping them in Ar and $\mathrm{N}_{2}$ matrices. The species obtained in the Ar matrix were $\mathrm{UO}, \mathrm{UO}_{2}$ and $\mathrm{UO}_{3}$, which represent the primary products of laser ablation. Charge transfer complexes, $\left(\mathrm{UO}_{2}^{+}\right)\left(\mathrm{O}_{2}^{-}\right)$and $\left(\mathrm{UO}_{2}^{2+}\right)\left(\mathrm{O}_{2}^{2-}\right)$ were also observed. In the $\mathrm{N}_{2}$ matrix, in addition to the primary ablation products, reaction products with nitrogen were also observed; the prominent among them being $\mathrm{UN}_{2}$ and NUO, together with their complexes with $\mathrm{N}_{2}$. Charge transfer complexes were also seen in these experiments. Features due to NO, $N_{3}$ and $N_{3}^{-}$were identified, which clearly point to the role of nitrogen in these reactions.
\end{abstract}

Keywords. Uranium oxide; matrix isolation; laser ablation; high temperature.

\section{Introduction}

Studies on high temperature chemistry have important applications in space and nuclear technology. In recent times, high temperature studies have received a further impetus due to the effective use of lasers to generate high temperatures. In combination with a variety of spectroscopy techniques, laser-ablation has been used to study high temperature behaviour of materials and their associated chemistry. One such technique is laser ablation matrix isolation spectroscopy, which in recent times has gained popularity for such studies (Vala et al 1990; Andrews et al 1992; Hunt and Andrews 1993; Hunt et al 1993; Andrews et al 1994; Kushto et al 1997).

In the matrix isolation technique, the species of interest is trapped along with a large excess of an inert gas, at low temperatures $(\approx 12 \mathrm{~K})$. The concentration of the species of interest $(S)$ in the matrix $(M)$ is typically about $1: 1000$ $(S: M)$, which ensures that the species, $S$, is surrounded only by the inert matrix atoms. Reactive molecules, such as those produced in a laser ablation process, when isolated in inert gas matrices, have extended lifetimes, simply for want of a reaction partner. The spectroscopy of these reactive species can then be studied leisurely.

Conventional high temperature studies have employed the Knudsen effusion methods (Gabelnick et al 1973a, b; Green and Reedy 1976; Green et al 1976). In this method, the material is heated in a Knudsen cell (K-cell) and species effusing out of the orifice are then studied using techniques, such as mass spectroscopy, torsion methods and infrared spectroscopy. While the Knudsen effusion method has met with unqualified success, one of its major

*Author for correspondence constraints has been its upper temperature limit. Experiments at temperatures above $2500 \mathrm{~K}$ pose serious problems with regard to production of high temperatures and associated sample-container reactions at these temperatures. For studies above $2500 \mathrm{~K}$ it is well nigh impossible to select an inert and stable container. Laser ablation offers an elegant solution to these problems. High intense laser beams when focused down to spot sizes of a few tens of microns generate temperatures in excess of $2500 \mathrm{~K}$ (Joseph et al 1997). Generation of high temperatures $(>2500 \mathrm{~K})$ using laser pulses is therefore experimentally trivial. Furthermore, the sample itself acts as its container and hence the container problem is also alleviated.

A number of studies have been reported where laser ablation has been combined with matrix isolation infrared spectroscopy to study the reactions of metal vapours produced at high temperatures (Vala et al 1990; Andrews et al 1992; Hunt and Andrews 1993; Hunt et al 1993; Andrews et al 1994; Kushto et al 1997). In particular, a number of studies by Andrews and coworkers have been made on the reactions of laser-ablated uranium with $\mathrm{O}_{2}$, $\mathrm{N}_{2}, \mathrm{NO}, \mathrm{NO}_{2}$ and $\mathrm{N}_{2} \mathrm{O}$ (Hunt and Andrews 1993; Hunt et al 1993; Kushto et al 1997). Various reaction products were observed with each of the reactant gases. With $\mathrm{O}_{2}$, the major species were $\mathrm{UO}, \mathrm{UO}_{2}$ and $\mathrm{UO}_{3}$, together with complexes of $\mathrm{UO}_{3}$ with $\mathrm{O}_{2}$; with $\mathrm{N}_{2}$, the major product was $\mathrm{UN}_{2}$ formed by an insertion of $\mathrm{U}$ into $\mathrm{N}_{2}$; while with $\mathrm{NO}, \mathrm{NO}_{2}$ and $\mathrm{N}_{2} \mathrm{O}$, products such as NUO, $[\mathrm{NUO}]^{+}\left[\mathrm{NO}^{-}\right.$, and $\mathrm{NUO}_{2}$ were observed. In each case, the major reaction was the insertion of uranium atom in the respective reactant molecule, such as $\mathrm{O}_{2}, \mathrm{~N}_{2}$, etc. While K-cell matrix isolation studies have been performed on $\mathrm{UO}_{2}$ in argon matrices, no laser ablation 
study of this material has been reported. We have therefore undertaken the present work to study the species formed over uranium oxide following laser ablation. Our study was motivated by two questions: First, how do the species produced by the laser ablation of $\mathrm{UO}_{2}$ compare with those obtained using K-cell evaporation? Secondly, what are the reaction products of the laser-ablated species of $\mathrm{UO}_{2}$ with $\mathrm{N}_{2}$ ? Would these reactions yield the mixed nitrogen-oxygen species of uranium, such as those observed by Andrews and coworkers in their laser ablation experiments with $\mathrm{NO}_{x}$ ?

\section{Experimental}

The low temperatures required for the matrix isolation work were obtained using a Leybold AG (model RD 210) closed cycle helium compressor cooled cryostat. The minimum temperature obtained with this system was $\approx 12 \mathrm{~K}$. The commercial cryostat was fitted with a homebuilt laser ablation cell. The laser ablation cell made of aluminum had the following provisions: a $40 \mathrm{~mm}$ flange fitted with a home-made veeco type coupling for holding the solid samples, a $40 \mathrm{~mm}$ port carrying a quartz window through which the laser beam was focused on the samples and two ports coaxial with substrate on the cold tip, each port being fitted with a $\mathrm{KBr}$ window for coupling the infrared beam of the FTIR into the cryostat. The laser ablation cell was connected to the main body of the cryostat through an ' $O$ ' ring seal. The schematic of the laser ablation matrix isolation setup is shown in figure 1 .

The laser ablation cell together with the main body of the cryostat was pumped using a $300 \mathrm{~L} \cdot \mathrm{s}^{-1}$ diffusion pump (Edwards Diffstak MK2), backed by a $200 \mathrm{~L} \cdot \mathrm{min}^{-1}$ rotary pump (Hind Hivac ED12). The base pressure in the vacuum chamber, measured using a Hind Hivac STP $4 \mathrm{M}$ penning gauge, was $<10^{-6}$ mbar.

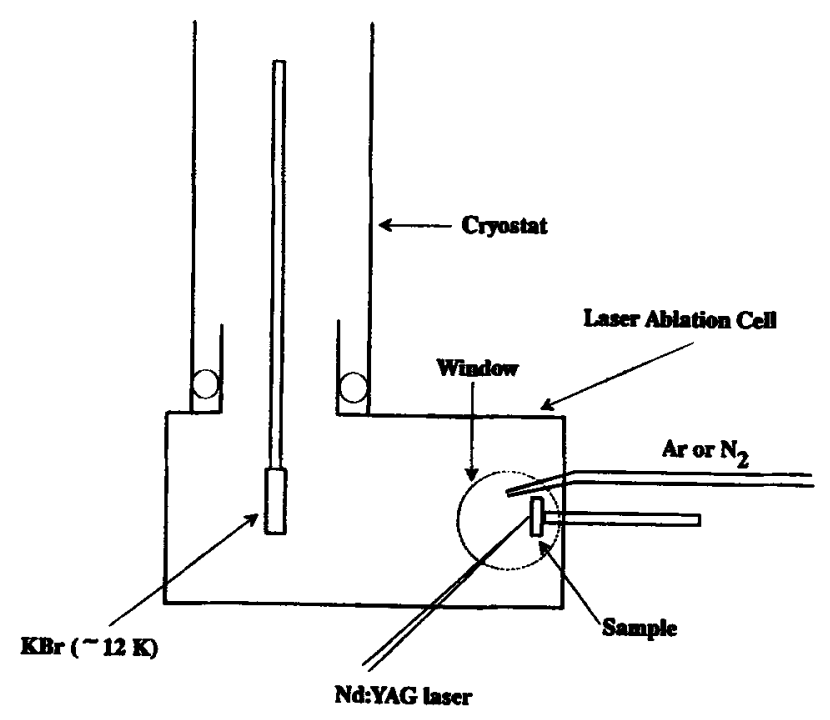

Figure 1. Schematic of the laser ablation cell.
High purity Ar and $\mathrm{N}_{2}$ (Grade I, Bhoruka Gases Limited, India) were used as matrix gases. A Leybold Heraeus variable leak valve was used to control the flow of the matrix gas during deposition. Typical flow rates used for deposition were $-3 \mathrm{mmol} / \mathrm{h}$.

The second harmonic $(532 \mathrm{~nm})$ of a pulsed $\mathrm{Nd}$ : YAG laser (continuum, model NY61-10), operated in the Qswitched mode, at a repetition rate of $10 \mathrm{~Hz}$ was used for ablation. The laser pulse had a temporal width of $\sim 10 \mathrm{~ns}$. Typically 20 to $40 \mathrm{~mJ}$ pulses were focused onto the sample, using a $75 \mathrm{~mm}$ focal length suprasil lens. The irradiance of such a focused beam was $\approx 10^{8}$ watts $/ \mathrm{cm}^{2}$, resulting in temperatures $>2500 \mathrm{~K}$ at the focal point on the sample. The uranium oxide sample used in these experiments was a single-phase, well-sintered pellet (Nuclear Fuel Complex, Hyderabad). The sample pellet was kept at a distance of $60 \mathrm{~mm}$ from the cold tip. The position of the laser beam on the sample was varied manually to expose a fresh surface to the laser beam continuously. This arrangement ensured efficient ablation during the entire course of the experiment, as repeated ablation of the same point on the sample lead to a drop in the ablation efficiency.

The laser-ablated species from the sample was mixed with a large excess of an inert gas and deposited on the cold $\mathrm{KBr}$ substrate placed at the cryotip $(\approx 12 \mathrm{~K}$ ); a typical deposition lasting for $\sim 30 \mathrm{~min}$ to an hour. An infrared spectrum of the deposited species was recorded using a BOMEM MB100 FTIR, at a resolution of $1 \mathrm{~cm}^{-1}$. The matrix was then warmed to $35 \mathrm{~K}$, held at this temperature for 15 minutes, recooled to $12 \mathrm{~K}$ and an infrared spectrum again recorded. Infrared spectra of such annealed matrices served to identify spectral features due to multiple trapping sites and also to drive reactions in the matrix.

We made no attempt to measure the temperature at the focal spot of the laser in our laser ablation matrix isolation experiments. A companion group in our laboratory using laser ablation mass spectroscopy had estimated the temperatures produced in these experiments, by measuring the time-of-arrival of the ablated species, from the point of ablation to the ionization source in the mass spectrometer. At the typical irradiances we had employed, they estimated the temperatures to be in excess of $2500 \mathrm{~K}$ (Joseph et al 1997).

\section{Results and discussions}

\subsection{Experiments using an argon matrix}

Figure 2a shows the infrared spectra of the laser-ablated species of uranium oxide, trapped in an argon matrix. The major peaks in this spectrum appeared at 776 and $820 \mathrm{~cm}^{-1}$. In addition, we also observed a number of peaks with moderate to weak intensities at $737,746,767$, 
$778,797,826,852,860,886$ and $952 \mathrm{~cm}^{-1}$. The intense spectral features are due to $\mathrm{UO}$ and $\mathrm{UO}_{2}$; the $820 \mathrm{~cm}^{-1}$ peak being due to UO and the $776 \mathrm{~cm}^{-1}$ peak being due to the $v_{3}$ vibration of $\mathrm{UO}_{2}$. The relatively weaker features at 746 and $852 \mathrm{~cm}^{-1}$ are due to the $v_{2}$ and $v_{4}$ vibrations of $\mathrm{UO}_{3}$. These assignments are based on the earlier K-cell matrix isolation work, where the vapour phase species over uranium oxide at a maximum temperature of $1900 \mathrm{~K}$, were trapped in an argon matrix (Gabelnick et al 1973b). The laser ablation process in which the temperatures at the sample were in excess of $2500 \mathrm{~K}$ has therefore yielded principally the same vapour phase species as the $\mathrm{K}$-cell work. However, in the laser ablation of $\mathrm{UO}_{2}$, features due to $\mathrm{UO}$ and $\mathrm{UO}_{2}$ were dominant, while in the $\mathrm{K}$-cell experiments, the major spectral features were due to $\mathrm{UO}_{2}$ and $\mathrm{UO}_{3}$. In experiments where uranium was laser-ablated in the presence of oxygen, the major reaction products were $\mathrm{UO}_{2}$ and $\mathrm{UO}_{3}$ (Hunt and Andrews 1993).

Figure $2 b$ shows the infrared spectrum recorded after the matrix was annealed at $35 \mathrm{~K}$. The most intense feature

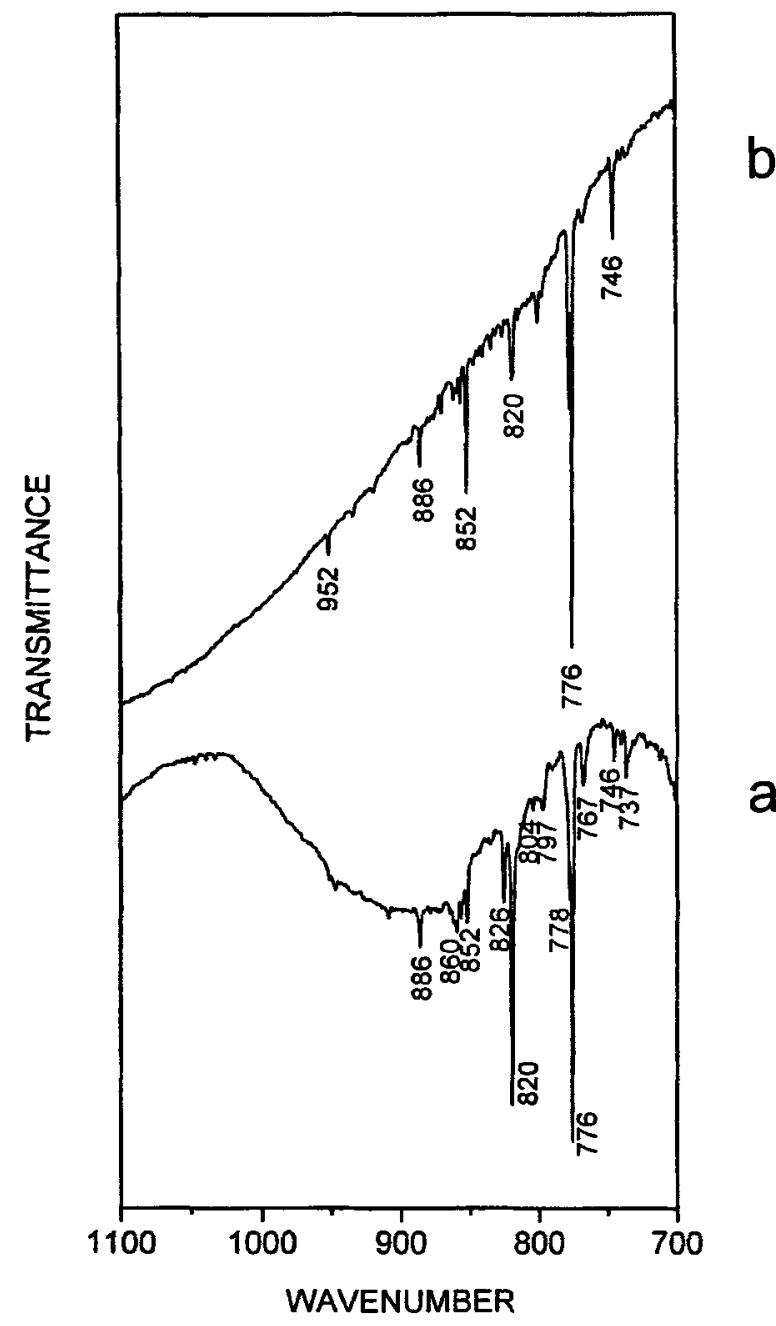

Figure 2. Matrix isolation infrared spectra of the laser-ablated species of uranium oxide trapped in an argon matrix; (a) before annealing; (b) matrix annealed at $40 \mathrm{~K}$. in figure $2 \mathrm{a}$ at $776 \mathrm{~cm}^{-1}$ corresponding to $\mathrm{UO}_{2}$ gained marginally, while the $852 \mathrm{~cm}^{-1}$ and $746 \mathrm{~cm}^{-1}$ peaks of $\mathrm{UO}_{3}$ gained somewhat more substantially in intensity. However, the intensity of the $820 \mathrm{~cm}^{-1}$ UO peak reduced drastically. This change in the intensity pattern on annealing was at variance with the observation made by Hunt and Andrews (1993). In their experiment, annealing the matrix at $30 \mathrm{~K}$ caused a marginal reduction in intensity of all the oxide peaks of uranium; namely UO, $\mathrm{UO}_{2}$ and $\mathrm{UO}_{3}$. The reduction in the intensity of the UO peak in our experiment is probably due to the reaction of at least part of the UO with atomic oxygen to form higher oxides; a reaction that probably needs little activation energy, as it appears to occur in the cryogenic matrix. As atomic and molecular oxygen are produced in the laser ablation of uranium oxide (Joseph et al 1997), atomic oxygen is expected to be available in the matrix.

The spectral features at $737,767,797,826$ and $860 \mathrm{~cm}^{-1}$ almost disappeared on annealing, indicating that these features may be due to uranium oxide species trapped in unstable sites. The $778 \mathrm{~cm}^{-1}$ feature persisted even on annealing and was probably due to $\mathrm{UO}_{2}$ trapped in a secondary site, in addition to the one corresponding to the $776 \mathrm{~cm}^{-1}$ feature. A similar satellite was also reported by Hunt and Andrews (1993).

The 886 and $952 \mathrm{~cm}^{-1}$ features had been assigned earlier by Andrews and Hunt to charge transfer complexes of $\left(\mathrm{UO}_{2}^{+}\right)\left(\mathrm{O}_{2}^{-}\right)$and $\left(\mathrm{UO}_{2}^{2+}\right)\left(\mathrm{O}_{2}^{2-}\right)$ respectively, in their laser ablation experiments of uranium metal with molecular oxygen (Hunt and Andrews 1993). Such species are likely to be formed in our experiments, because as mentioned earlier, laser ablation of uranium oxide does produce molecular oxygen. The reaction of molecular oxygen with $\mathrm{UO}_{2}$ is likely to lead to the formation of charge transfer complexes. In the experiments of Andrews, multiplets were observed, associated with these complexes, and the multiplets were suspected to arise from the different orientations of the ion pair. However, in our experiments only the 886 and $952 \mathrm{~cm}^{-1}$ features were observed.

\subsection{Experiments using a nitrogen matrix}

Figure 3a shows the infrared spectrum of the laser-ablated species of uranium oxide trapped in a $\mathrm{N}_{2}$ matrix. The major features were at 878 and $996 \mathrm{~cm}^{-1}$. Features were also observed at $768,774,785,795,846,890,938,939$ and $1008 \mathrm{~cm}^{-1}$. This spectrum is substantially different from that observed when an Ar matrix was used, indicating that $\mathrm{N}_{2}$ either induces severe matrix perturbations or reacts chemically with the laser-ablated species.

Our experiments using $\mathrm{Ar}$ as the matrix indicated that $\mathrm{UO}, \mathrm{UO}_{2}$ and $\mathrm{UO}_{3}$ were the major species produced in the laser ablation of uranium oxide. The same species must be produced in the experiments when $\mathrm{N}_{2}$ was used as the matrix. The features at $795,785,774$ and 768 can be 
attributed to $\mathrm{UO}$ and $\mathrm{UO}_{2}$ in the $\mathrm{N}_{2}$ matrix, as these features appear close to the $\mathrm{Ar}$ values of 820 and $776 \mathrm{~cm}^{-1}$ for these species. The exact assignments of these features will be discussed later.

Figure $3 \mathrm{~b}$ shows the infrared spectrum recorded after the matrix was annealed at $35 \mathrm{~K}$. The intense $996 \mathrm{~cm}^{-1}$ absorption gained further, but the other major feature at $878 \mathrm{~cm}^{-1}$ reduced marginally in intensity. The $890 \mathrm{~cm}^{-1}$ product absorption also gained in intensity. A feature at $960 \mathrm{~cm}^{-1}$ (which was not discernible in the pre-annealed spectra) picked up in intensity after annealing. For all other peaks, changes in intensities were moderate.

3.2a Reactions in the nitrogen matrix: The absorption at $996 \mathrm{~cm}^{-1}$ in the nitrogen matrix is one evidence of reactions in this matrix. This feature was observed by Andrews and coworkers in their experiments where

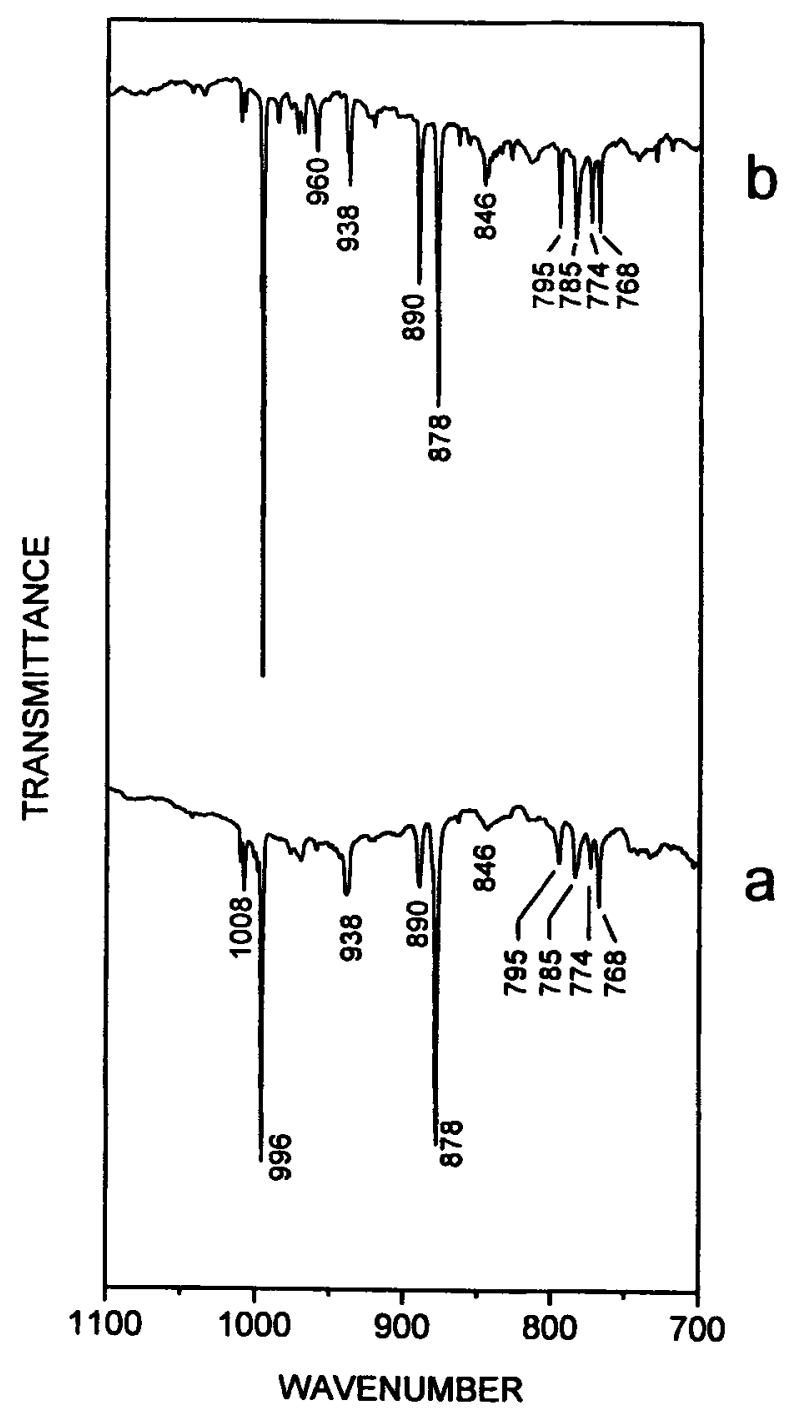

Figure 3. Matrix isolation infrared spectra of the laser-ablated species of uranium oxide trapped in a nitrogen matrix; (a) before annealing; (b) matrix annealed at $35 \mathrm{~K}$. uranium vapours were deposited in the nitrogen matrix and was assigned to $\mathrm{UN}_{2}$ in a nitrogen cage (Hunt et al 1993). The $996 \mathrm{~cm}^{-1}$ feature in our spectrum can also be attributed to $\mathrm{UN}_{2}$ which is produced in the nitrogen matrix as a result of the reaction of the primary products of ablation (i.e. $\mathrm{U}, \mathrm{UO}, \mathrm{UO}_{2}$ and $\mathrm{UO}_{3}$ ) with reactive nitrogen. The dinitride is probably formed by an insertion of $U$ into $N_{2}$, or by a reaction of $U_{x}$ with reactive nitrogen species, such as $\mathrm{N}_{3}$ or $\mathrm{N}_{3}^{-}$. The presence of these azide species in the nitrogen matrix experiments was indicated by the absorptions at $1658 \mathrm{~cm}^{-1}$ and $2003 \mathrm{~cm}^{-1}$ due to $\mathrm{N}_{3}$ and $\mathrm{N}_{3}^{-}$respectively (Tian et al 1988; Chertihin et al 1996).

Nitric oxide (NO) was another reaction product in our nitrogen matrix experiments identified by its absorption at $1875 \mathrm{~cm}^{-1}$. With atomic oxygen produced in the laser ablation process, and reactive nitrogen species such as $\mathrm{N}_{3}$ present in the matrix, it is not surprising to observe NO in these experiments. Please note that the spectra shown in figures 2 and 3, span only the region where the uranium species absorb; the region where the features of $\mathrm{NO}, \mathrm{N}_{3}$ and $\mathrm{N}_{3}^{-}$occur have not been shown.

\subsection{Experiments using mixed matrix $\left(\mathrm{N}_{2} / \mathrm{Ar}\right)$}

To identify the species responsible for the features at 938 , $890,878 \mathrm{~cm}^{-1}$ and the quartet near $780 \mathrm{~cm}^{-1}$ observed in the nitrogen matrix, we performed experiments using mixed $\mathrm{N}_{2} / \mathrm{Ar}$ matrices. In these experiments, the concentrations of $\mathrm{N}_{2}$ in the matrix gas mixture were varied over the range $1 \%$ to $50 \%$. The corresponding spectra are shown in figure 4 . Due to the complexity of these spectra, we will separately discuss the features of each product in different matrices, albeit at the expense of being repetitious.

$U_{2}$ : The feature for this product occurred at $776 \mathrm{~cm}^{-1}$ in pure $\mathrm{Ar}$ and in Ar matrices containing up to $3 \% \mathrm{~N}_{2}$. With further increase in $\mathrm{N}_{2}$, this feature splits and is probably responsible for at least some of the peaks in the quartet observed near $780 \mathrm{~cm}^{-1}$ in pure $\mathrm{N}_{2}$.

UO: This product is evidenced by a feature at $820 \mathrm{~cm}^{-1}$ in pure Ar. As the $\mathrm{N}_{2}$ concentration was increased the features due to these products decreased in intensity. A later discussion will serve to identify the feature due to this species (and also that due to $\mathrm{UO}_{2}$ ) in the $\mathrm{N}_{2}$ matrix.

$\mathrm{UO}_{3}$ : The features due to this product are observed at 852 and $746 \mathrm{~cm}^{-1}$ in pure Ar. As the $\mathrm{N}_{2}$ concentration was increased, it was difficult to discern features due to this species. It appears that $\mathrm{UO}_{3}$ is unstable in the conditions existing when trapped in a $\mathrm{N}_{2}$ matrix.

$U N_{2}$ : Not surprisingly, this product was not observed in pure Ar for want of $\mathrm{N}_{2}$ to form the nitride. In matrices containing less than $1 \%$ of $\mathrm{N}_{2}$, a feature was observed at $1051 \mathrm{~cm}^{-1}$, which was assigned to $\mathrm{UN}_{2}$. As the $\mathrm{N}_{2}$ concentration was increased, new features appeared at 
$1040,1032,1021,1012$, in excellent agreement with the earlier report of Andrews (Hunt et al 1993). These features were attributed to $\mathrm{UN}_{2}$ complexing progressively with increasing amounts of $\mathrm{N}_{2}$; the $1040 \mathrm{~cm}^{-1}$ feature to $\left(\mathrm{UN}_{2}\right)\left(\mathrm{N}_{2}\right)$ and the $1012 \mathrm{~cm}^{-1}$ peak to $\left(\mathrm{UN}_{2}\right)\left(4 \mathrm{~N}_{2}\right)$. In pure nitrogen, $\mathrm{UN}_{2}$ was reported to occur at $996 \mathrm{~cm}^{-1}$, in agreement with our observations; though alternate explanations appear possible.

NUO: In matrices containing $1 \% \mathrm{~N}_{2}$, this product was observed by its spectral feature at $984 \mathrm{~cm}^{-1}$, with a satellite at $974 \mathrm{~cm}^{-1}$. As with $\mathrm{UN}_{2}, \mathrm{NUO}$ is also probably

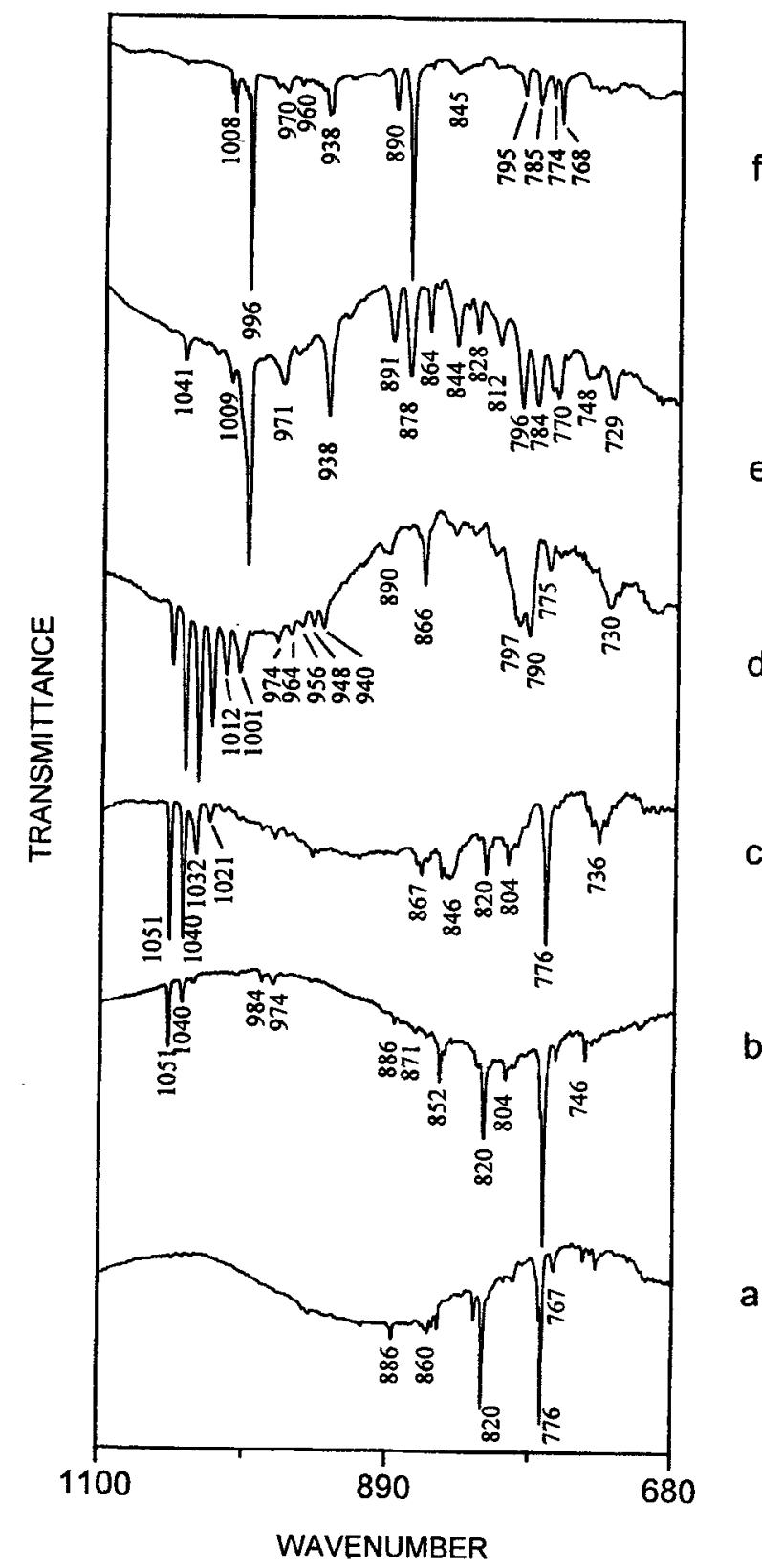

Figure 4. Matrix isolation infrared spectra of the laser-ablated species of uranium oxide trapped in mixed nitrogen/argon matrices. Concentrations of $\mathrm{N}_{2}$ in the $\mathrm{Ar} / \mathrm{N}_{2}$ mixture were (a) $0 \%$; (b) $1 \%$; (c) $3 \%$; (d) $12.5 \%$; (e) $50 \%$; (f) $100 \%$. All spectra were recorded before annealing the matrix. formed by the reaction of $\mathrm{UO}_{\mathrm{x}}$ with reactive nitrogen species. As the $\mathrm{N}_{2}$ concentration was increased, new features appeared at $964,956,948$ and $940 \mathrm{~cm}^{-1}$, very similar to the structure observed with $\mathrm{UN}_{2}$. We therefore infer, that (NUO) $\left(\mathrm{xN}_{2}\right)$ complexes are formed similar to the $\left(\mathrm{UN}_{2}\right)\left(\mathrm{xN}_{2}\right)$ complexes. Each of the features from 964 to $940 \mathrm{~cm}^{-1}$ can be assigned to complexes with progressively increasing amounts of $\mathrm{N}_{2}$; the $964 \mathrm{~cm}^{-1}$ feature to (NUO) $\left(\mathrm{N}_{2}\right)$ and the $940 \mathrm{~cm}^{-1}$ peak to (NUO) $\left(4 \mathrm{~N}_{2}\right)$. The $938 \mathrm{~cm}^{-1}$ feature in the $\mathrm{N}_{2}$ matrix can therefore be assigned to NUO in a $\mathrm{N}_{2}$ cage.

The feature at $984 \mathrm{~cm}^{-1}$ (Ar matrix) was assigned to UN stretch in the NUO molecule, while the UO vibration in this species was believed to occur near $820 \mathrm{~cm}^{-1}$, at exactly the same position where the diatomic UO absorbed (Kushto et al 1997). The question now arises as to where the UO absorption occurs in the nitrogen matrix. We examined the possibility that one (or more, if site effects come into play) of the quartet of peaks in the nitrogen matrix near $780 \mathrm{~cm}^{-1}$ may be due to the UO stretch in the NUO molecule or diatomic UO. We calculated the intensity ratios of the $938 \mathrm{~cm}^{-1}$ feature with each of the peaks in the $780 \mathrm{~cm}^{-1}$ quartet, for four sets of repeat experiments in the nitrogen matrix, performed on four different days. The values are shown in table 1. It can be seen that while the $938 / 795$ ratio remains fairly constant in the different experiments, the other ratios show a scatter. This data suggests that the intensity of the 938 and $795 \mathrm{~cm}^{-1}$ features is correlated and must belong to the same species. We therefore believe that the $795 \mathrm{~cm}^{-1}$ feature must be due to the UO stretch in the NUO molecule (or in the UO diatomic), while the $938 \mathrm{~cm}^{-1}$ feature (which had been assigned to the NUO species earlier), must be due to the UN stretch. The three other features in the ' 780 quartet' may be assigned to $\mathrm{UO}_{2}$, the triplet arising possibly due to multiple site effects.

It may be relevant to note that in the experiments of Andrews et $a l$ where laser-ablated uranium vapour was reacted with NO, the NUO molecule was produced by the insertion of $U$ into the NO molecule (Kushto et al 1997). In our experiments, where solid $\mathrm{UO}_{2}$ was laser-ablated in the presence of $\mathrm{N}_{2}$, the NUO molecule could probably

Table 1. Intensity ratios of the $938 \mathrm{~cm}^{-1}$ feature with each of the feature in the quartet near $780 \mathrm{~cm}^{-1}$, in four different repeat experiments in the nitrogen matrix.

\begin{tabular}{lcccc}
\hline Experiment & $I_{938} / I_{795}$ & $I_{938} / I_{785}$ & $I_{938} / I_{774}$ & $I_{938} / I_{768}$ \\
\hline 1. Before annealing & 1.23 & 1.20 & 2.95 & 1.32 \\
After annealing & 1.54 & 0.95 & 1.95 & 1.65 \\
2. Before annealing & 0.96 & 0.47 & 0.97 & 1.17 \\
After annealing & 1.25 & 0.82 & 0.68 & 3.01 \\
3. Before annealing & 1.09 & 0.55 & 0.94 & 0.59 \\
After annealing & 1.13 & 0.65 & 0.53 & 1.13 \\
4. Before annealing & 1.15 & 0.42 & 1.18 & 0.46 \\
After annealing & 1.56 & 0.88 & 0.79 & 0.81 \\
\hline
\end{tabular}


have been produced by the reaction of UO with nitrogen atoms, in the matrix; in keeping with the observation that the intensity of the UO peak decreased with increase in the $\mathrm{N}_{2}$ concentration.

$\left(U \mathrm{O}_{2}^{+}\right)\left(\mathrm{NO}^{-}\right)$: In experiments containing $1 \% \mathrm{~N}_{2}$ in the matrix gas mixture, features appeared at 886 and $871 \mathrm{~cm}^{-1}$, which agree quite well with the values $(880$ and $869 \mathrm{~cm}^{-1}$ ) reported for $\left(\mathrm{UO}_{2}^{+}\right)\left(\mathrm{NO}^{-}\right)$in an $\mathrm{Ar}$ matrix (Kushto et al 1997). On increasing the $\mathrm{N}_{2}$ concentration, the $871 \mathrm{~cm}^{-1}$ feature increased in intensity and finally appeared as a strong peak at $878 \mathrm{~cm}^{-1}$ in the pure $\mathrm{N}_{2}$ matrix. The $886 \mathrm{~cm}^{-1}$ feature that appeared in the $\mathrm{Ar}$ rich matrix, appeared at $890 \mathrm{~cm}^{-1}$ in $\mathrm{N}_{2}$. The 890 and $878 \mathrm{~cm}^{-1}$ features in the $\mathrm{N}_{2}$ matrix are therefore most likely due to $\left(\mathrm{UO}_{2}^{+}\right)\left(\mathrm{NO}^{-}\right)$in $\mathrm{N}_{2}$. The charge transfer complexes involving $\mathrm{NO}$ are possible since as mentioned earlier NO is one of the reaction products in these experiments. It must be mentioned that the $878 \mathrm{~cm}^{-1}$ feature was also observed by Hunt et al (1993), though no assignment was proposed in that work.

Based on the work of Kushto et al (1997), $\left(\mathrm{UO}_{2}^{-}\right)\left(\mathrm{N}_{2}^{-}\right)$may also be considered as a likely candidate for the spectral features near $880 \mathrm{~cm}^{-1}$. Electron attachment to $\mathrm{N}_{2}$ is endothermic by $1.6 \mathrm{eV}( \pm 1.0 \mathrm{eV})$ (Chase et al 1985) and the overall reaction

$$
\mathrm{UO}_{2}+\mathrm{N}_{2} \rightarrow\left(\mathrm{UO}_{2}^{+}\right)\left(\mathrm{N}_{2}^{-}\right) \text {, }
$$

is endothermic and has a $\Delta H$ of $164 \mathrm{kcal} / \mathrm{mol}$, compared with a value of $126 \mathrm{kcal} / \mathrm{mol}$ for $\left(\mathrm{UO}_{2}^{+}\right)\left(\mathrm{NO}^{-}\right)$(Green et al 1976). Both the endothermic reactions are expected to be stabilized in the matrix by Coulombic attraction. Assuming a point charge model and a cation-anion distance of $3.5 \AA$, typical of adjacent sites in an inert matrix, the Coulombic stabilization would amount to $\approx 95 \mathrm{kcal} / \mathrm{mol}$. Though this value appears insufficient to stabilize either of these complexes, the point charge model should only be considered to provide an estimate for the interaction energy, and it is more likely that the Coulombic interaction would aid the formation of the ( $\mathrm{UO}_{2}^{+}$(NO) rather than $\left(\mathrm{UO}_{2}^{+}\right)\left(\mathrm{N}_{2}^{-}\right)$. However, given the rather large uncertainty in the electron affinity of $\mathrm{N}_{2}$, we draw this conclusion with caution. (In the above calculation, the ionization potential of $\mathrm{UO}_{2}$, reported by Mann (1964) was used).

It may be noted that the spectra became complex when the concentration of $\mathrm{N}_{2}$ in Ar was $>10 \%$, probably due to multiple trapping sites that may be produced in mixed matrices.

While $\mathbf{N}_{2}$ has been employed in a number of matrix isolation experiments as an inert matrix, this matrix has thrown up a variety of interesting reactions in laser ablation experiments. The inert matrix manifesting reactivity is a feature of laser ablation experiments, where ablated species with high kinetic energies can induce hyperthermal reactions (Friichtenicht 1974; Kang and Beauchamp 1985).

\section{Conclusions}

This study reports for the first time the matrix isolation infrared spectra of laser-ablated uranium oxide species trapped in $\mathrm{Ar}$ and $\mathrm{N}_{2}$ matrices. The species obtained in the Ar matrix, $\mathrm{UO}, \mathrm{UO}_{2}$ and $\mathrm{UO}_{3}$, represent the primary products of laser ablation. In the nitrogen matrix, in addition to the primary laser-ablated species, reaction products of these ablated species with reactive nitrogen were also observed. $\mathrm{UN}_{2}$ and $\mathrm{NUO}$, together with their complexes with $\mathrm{N}_{2}$, were the dominant reaction products. Charge transfer complex $\left(\mathrm{UO}_{2}{ }^{+}\left(\mathrm{NO}^{-}\right)\right.$was also observed in these experiments, as also features due to $\mathrm{NO}, \mathrm{N}_{3}$ and $\mathrm{N}_{3}$.

It may be interesting to note that all the species observed in this single study, where uranium oxide was laser-ablated in the presence of $\mathrm{Ar}$ and $\mathrm{N}_{2}$, represent the products observed in a collection of separate experiments reported previously, where uranium metal was laser vapourized in the presence of $\mathrm{O}_{2}, \mathrm{~N}_{2}, \mathrm{NO}, \mathrm{NO}_{2}$ and $\mathrm{N}_{2} \mathrm{O}$.

\section{Acknowledgement}

We gratefully acknowledge the assistance rendered by our colleagues at the Chemical Group Workshop in the design and fabrication of the laser ablation cell.

\section{References}

Andrews L, Burkholder T R and Yustein J T 1992 J. Phys. Chem. 9610182

Andrews L, Yustein J T, Thomson C A and Hunt R D $1994 \mathrm{~J}$. Phys. Chem. 986514

Chase M W Jr., Davies C A, Downey J R Jr., Frurip D J, McDonald R A and Syverud A N 1985 JANAF thermochemical tables, 3rd Edition, J. Phys. and Chem. Reference Data 14 Suppl. 11553

Chertihin G V, Andrews L and Neurock M 1996 J. Phys. Chem. 10014609

Friichtenicht J F 1974 Rev. Sci. Instrum. 4551

Gabelnick S D, Reedy G T and Chasanov M G 1973a Chem. Phys. Lett. 1990

Gabelnick S D, Reedy G T and Chasanov M G 1973b J. Chem. Phys. 584468

Green D W and Reedy G T 1976 J. Chem. Phys. 652921

Green D W, Gabelnick S D and Reedy G T 1976 J. Chem. Phys. 641697

Hunt R D and Andrews L 1993 J. Chem. Phys. 983690

Hunt R D, Yustein J T and Andrews L $1993 \mathrm{~J}$. Chem. Phys. 98 6070

Joseph M, Sivakumar N, Alber Raj and Mathews C K $1997 \mathrm{~J}$. Nucl. Mater. 24721

Kushto G P, Souter P F, Andrews L and Neurock M $1997 \mathrm{~J}$. Chem. Phys. 1065894

Kang H and Beauchamp J L 1985 J. Phys. Chem. 893364

Mann J B 1964 J. Chem. Phys. 401632

Tian R, Facelli J C, Michl J 1988 J. Phys. Chem. 924073

Vala M, Chandrasekar T M, Szczepanski J and Pellow R 1990 High Temp. Sci. 2719 